\title{
Review \\ Principles of Nudging and Boosting: Steering or Empowering Decision-Making for Behavioral Development Economics
}

\author{
Victor I. Espinosa ${ }^{1, *(\mathbb{C})}$, William Hongsong Wang ${ }^{2, *(\mathbb{C}}$ and Jesús Huerta de Soto $^{3}(\mathbb{D}$ \\ 1 Department of Business Administration, Universidad Autónoma de Chile, Providencia 7500912, Chile \\ 2 Facultad de Ciencias Económicas, Universidad Francisco Marroquín (Madrid Campus), \\ Calle de Arturo Soria 245, 28033 Madrid, Spain \\ 3 Department of Applied Economics I, History and Economic Institutions and Moral Philosophy, Social and \\ Legal Sciences Faculty, Rey Juan Carlos University, 28033 Madrid, Spain; huertadesoto@dimasoft.es \\ * Correspondence: victor.espinosa@uautonoma.cl (V.I.E.); hongsongwang@ufm.edu (W.H.W.)
}

check for updates

Citation: Espinosa, V.I.; Wang, W.H.; Huerta de Soto, J. Principles of Nudging and Boosting: Steering or Empowering Decision-Making for Behavioral Development Economics. Sustainability 2022, 14, 2145. https:// doi.org/10.3390/su14042145

Academic Editor: Leonardo Becchetti

Received: 24 November 2021

Accepted: 9 February 2022

Published: 14 February 2022

Publisher's Note: MDPI stays neutral with regard to jurisdictional claims in published maps and institutional affiliations.

Copyright: (C) 2022 by the authors. Licensee MDPI, Basel, Switzerland. This article is an open access article distributed under the terms and conditions of the Creative Commons Attribution (CC BY) license (https:// creativecommons.org/licenses/by/ $4.0 /)$.

\begin{abstract}
Behavioral development economics promotes the nudge theory as a mechanism to incorporate people's cognitive biases, steering their behavior in the desired direction through coercive state intervention. Cognitive biases become a reason to doubt the efficiency of decision-making psychology in the free market process. A fundamental assumption of this approach is that political decision-makers know the people's means and ends in ways that protect them from cognitive biases. This article reviews and discusses the nudge theory, based on the boost theory developed by the Austrian School of Economics. The boost theory consists of a comparative institutional perspective to provide the empowerment people need to realize their errors and correct them "on the fly" to cultivate economic development. It is argued that the nudge theory overlooks the cognitive biases of political decision-makers, neglects the comparative perspective of the institutional environment in the face of such biases, and does not consider how construction of on-the-fly judgments works. After reviewing the principles of the nudge theory, its main criticisms from the boost theory are discussed, forming novel conclusions about and research avenues on behavioral development economics, according to the steering or empowering quality of the institutional environment.
\end{abstract}

Keywords: entrepreneurship; judgment; institutions; cognition; psychology of decision-making; behavioral economics; decision environment; economic development

\section{Introduction}

It is not difficult to find evidence that people often make decisions that harm their wellbeing or the well-being of others [1,2]. These "cognitive biases" are the psychological effect that distorts our perception of reality, such as systematic misinterpretations of the available information that influences processing thoughts and making decisions and judgments [3-5]. Cognitive biases occur when our brain disrupts its evaluations, perceptions, decisionmaking psychology, and memory itself. It is the case, for example, of people who support or oppose a specific topic and not only seek information to reinforce their thesis but also interpret it in a way that defends their preconceptions. Many people maintain established behaviors unless there is a compelling incentive to change. Some people make weak financial decisions, such as not saving enough for retirement. Others have unhealthy lifestyles, and a few adopt green behavior to protect the environment. As some behavioral economists say, cognitive bias raises "serious questions about the rationality of many judgments and decisions that people make" [2]. The experimental evidence seems to support the existence of scenario patterns in which judgments and decisions were not based on predictability according to "rational choice theory" [6-8]. This evidence supported these differences by finding the key to heurism, intuitive processes that are usually the source of systematic cognitive biases. 
In the past decade, development economics has increasingly incorporated the theories and methods of behavioral economics, giving birth to behavioral development economics as a subfield to analyze questions about economic development. A recent body of work suggests that living in poverty can directly affect cognitive function and economic behaviors, potentially exacerbating cognitive biases and deepening poverty [9-13]. Poverty impedes the cognitive function of the poor by capturing human minds with money-related thoughts, thus mental bandwidth available for other tasks is reduced. If poverty itself can degrade decision-making quality and reduce productivity, cognitive biases become a reason to doubt the dynamic efficiency of decision-making psychology in the free market process [14]. In this sense, behavioral development economics promotes nudge theory to suggest several ways coercive state interventionism can steer people's behavior towards abolishing cognitive biases in welfare-promoting directions. A fundamental assumption of nudge theory is that benevolent political decision-makers diligently structure nudges to steer ends consistent with the ultimate goals and people's objective judgments as to the driving force of economic development [15-18]. However, is it reasonable to take at face value the assumption that political decision-makers know the people's means and ends in ways that protect them from cognitive biases?

This article reviews and discusses the nudge theory based on the boost theory developed by the Austrian School of Economics. The boost theory consists of a comparative institutional perspective to empower people to realize their mistakes and correct them on the fly (i.e., an open-ended learning process) to cultivate economic development. It is argued that the nudge theory overlooks the cognitive biases of political decision-makers, neglects the comparative institutional on the private property rights perspective, and does not consider how the construction of on-the-fly judgments works. The second section explains the theoretical framework and methodology used in the research. After reviewing the principles of the nudge theory, the third section addresses the boost theory from an economic and psychological point of view to compare its main conclusions with the nudge theory. The concept of cognitive bias is applied to political decision-makers to explain how the theoretical application of steering and empowering affects the psychological self-confidence of the poor to cultivate economic development. The fourth section then addresses the broader question of market failures, and the state's role in defining steering and empowering people's judgment and behavior in economic development.

\section{Theoretical Framework and Methodology}

This review uses the economic theory of the Austrian School of Economics (well known as Austrian Economics) and some other fundamental principles of political economy and psychology of decision-making [19-22]. In this way, a robust theory of economics and psychology is used to understand and interpret economic development sustainability. Unlike the physical sciences, the human sciences begin with individuals' subjective purposes and plans. Subjectivism implies that human action begins an open-ended evolving process, where time cannot pass without modifying knowledge. Social reality can be seen as a kaleidic society, interspersing its moments or intervals of subjective perspectives order with sudden disintegration and cascading into new patterns. Economic logic is an evident and indispensable truth for all human minds, centered on action cognition. That is, there is something that consciously points to ends. As a result, the goal of the sciences of human action is intelligibility (pattern predictions) from chains of cause and effect, which constitute and generate a definite process driven by the purposefulness of human action. The usefulness of quantitative prediction is auxiliary and illustrative to economic theory: a behavior change is linked to a change in knowledge, and future knowledge cannot be obtained before its time. While some of these essential principles are widely known, others are an "open secret", especially for all those who fall into the trap of feeding populist demagoguery by creating false and unattainable expectations. The latter is the case of omnipotent and meddlesome states that steer a set of default values on the poor through 
dispense subsidies and privileges, whose institutional coercion is the essence of poverty and underdevelopment $[23,24]$.

\section{Review Key-Points, Literature and History}

\subsection{The Nudge Theory: The Behavioral Development Economics Approach}

From the earliest work in economics, many theorists explained that people can make judgment errors and that the institutional and cultural environment shapes their cognitive function $[9,25]$. Yet, economists such as Walras, Edgeworth, Jevons, Marshall, Fisher, and Pareto, among many others, were pioneers in introducing mathematical methods into economics, beginning to build neoclassical theory in the 1870s with a different approach to people's behavior [26-28]. Neoclassical theory assumes that people have unbounded rationality and exogenous judgments in an environment of given ends and means. The homo economicus approach to a rational choice theory promises to explain and predict the best alternative for people in their social and economic activities through hypotheses and models $[29,30]$. Regardless of how many economists believe that rational choice theory adequately describes how people make decisions in real life, adopting the neoclassical approach is widely accepted as the best behavior model in economic contexts [31,32]. Following these patterns, growth and development economics apply neoclassical theory to rational choice problems in the market through empirical work, especially experiments or quasi-experiments. Although the field of experiments is considered fundamental to steer market outcomes, studies generally show that individual rationality does not contribute to an efficient global market equilibrium [33,34].

In recent decades, economists have attempted to explain changes in people's behavior into neoclassical theory [35]. It began with psychologists Daniel Kahneman and Amos Tversky, who studied the rational choice theory delusions [36,37]. Their research led to new works integrated into behavioral economics, an economics-based psychology discipline, and discarded the homo economicus approach to propose that people can be irrational, quasi-rational, or possess limited rationality $[38,39]$. Hence, rational choice problems are due to cognitive biases, a systematic misinterpretation of available information that affects thought processing in people's judgment and behavior. Cognitive bias arises from various cerebral processes that are sometimes difficult to distinguish. These include information processing through shortcuts, emotional and moral motivations, or social influence. Consequently, behavioral economists try to identify the systematic cognitive errors of people in their decision-making and, thus, promote public policies to encourage some behaviors and repress others [40].

Many neoclassical development economists have recently incorporated behavioral economics theories and methods into the psychology of poverty, giving rise to the subfield of behavioral development economics [10,41]. This body of work suggests that living in poverty can undeviatingly affect cognitive function and economic behaviors, exacerbating cognitive biases and deepening poverty. For example, a poor person is worried about paying rent, their children's college fees, cellphone bills, or an adverse illness. Any unexpected shock could cause their financial ruin. In this sense, poverty itself generates cognitive biases among the poor, degrading their quality of decision-making and reducing their productivity. If the cognitive ability of the poor is limited to money-related thoughts, the mental bandwidth available for other tasks is low [42]. Poverty poses many other deprivations and potentially detrimental situations, such as low income, malnutrition, unhealthy lifestyle, high levels of stress, and lack of access to education and medical care [43-45]. Moreover, poverty usually leads to social stigma, shame, and social exclusion, which then turn into a financial constraint that could raise cognitive biases in harmful decision-making. Many poor people are exposed to these factors above, so it would be valuable to highlight the link between them in the poverty jam.

Behavioral development economics is built on the premise that "in many cases, individuals make pretty bad decisions-decisions they would not have made if they had paid full attention and possessed complete information, unlimited cognitive abilities, and 
complete self-control" [2]. Cognitive biases can perversely influence how the poor face self-control problems, such as financial decisions and political processes [46-48]. The behavioral development literature points to accepting these problems as given and challenging to eliminate, arguing that steering the poor is an effective and ethical strategy for political decision-makers $[49,50]$. It is the nudge theory that explains how political decision-makers can design institutional mechanisms to steer (govern) the behavior of the poor towards improving well-being at both individual and group levels [51]. On the one hand, the nudge approach assumes that the ends and means of the people are given to the political decision-maker. On the other hand, its promise to generate efficient development policy mechanisms is driven by coercive state intervention. Steering pursues well-intentioned political goals, which do not conflict with the well-being of the poor.

Nudge policies that preserve the freedom of choice of the poor by implementing easily reversible options are often part of the so-called soft or libertarian paternalism [1,52]. The classic example of libertarian paternalism is a policy with an automatic default option that forces some outcomes but allows people to opt out of the default rules. Libertarian paternalists suggest that the nudges will be better if they set default values on the poor welfare enhancement option. If individuals remain free to deviate from the default option, they argue, the libertarian should not be bothered by this paternalistic form of coercive state intervention in the economic system. In contrast, the imputation policies that influence coercive judicial orders (e.g., regulations or taxes) are called hard or socialist paternalism [53,54]. If socialist paternalists consider that the poor often produce suboptimal outcomes by the political decision-makers criteria, coercive state intervention must "help" the poor make their decisions to reduce systematic cognitive biases in the way they think. The goal of socialist paternalism is to steer the poor out of cognitive biases in welfare-promoting directions. Despite the apparent differences, libertarian and socialist paternalists agree that it is wrong or old-fashioned to claim that nudge designers cannot steer and develop market outcomes [55]. These two political approaches to nudge theory have a substantial influence on public policy debates worldwide.

\subsection{Nudge versus Boost: Retrospect and Prospect}

In behavioral development economics, nudging involves changing the environment where people make decisions to bridge poverty and development gaps [56]. The fundamental assumption is that market participants have cognitive biases, which psychologically well-informed regulators should rectify. If political decision-makers know people's ends and means (at least, better than people do!), they can defeat cognitive biases to cultivate economic development through coercive state interventionism [57]. However, is it reasonable to take at face value the assumption that political decision-makers know the people's means and ends in ways that protect them from cognitive biases? The scientific significance of this question lies in the fact that the knowledge of the environment that regulators must make use of only exists as scattered fragments of incomplete and often contradictory knowledge that people possess. Society's main problem is not simply a problem of allocating a "given" range of people's ends and means, if "given" is understood as given to a single mind deliberately solving the poverty problem posed by these "data". Instead, the main problem is how the institutional environment based on private property rights can ensure the best use of the resources known to any of the members of society, for purposes whose relative importance only these individuals know. As Hayek writes, "it is a problem of the utilization of knowledge not given to anyone in its totality" [58]. Most importantly, without the institutions of private property rights, there would be no price coordination, and without price coordination, no resource allocation problem could be solved by the given resource thesis of the paternalists.

Regardless of their intentions, political decision-makers also consist of imperfect actions with cognitive biases, making it evident that the nudge theory has some biases and delusions for behavioral development economics. Austrian Economics offers an alternative to libertarian or socialist paternalism: empowering people to avoid their cognitive biases 
on the fly (i.e., an open-ended learning process) to improve their well-being without coercive state interventionism [59]. The boost theory explains how people undertake entrepreneurship to identify human problems and how the institutional environment empowers people's ability and willingness to solve them. The following economic and psychological analysis presents the boost theory from Austrian Economics and contrasts its main findings on cognitive biases, institutional environment, and construction of on-the-fly judgments with the nudge theory. The central issue in the discussion between steering and empowering the rationality of people is the extent to which people can overcome their biases and cultivate economic development. On the one hand, steering implies that humans are essentially hostages to a fast and automatic cognition system. On the other hand, empowering implies that individual decision-making and motivation skills can be improved through the institutional environment, building and expanding people skills and psychological self-confidence through the entrepreneurial market process.

\subsubsection{The Boost Theory: The Economic Point of View}

Austrian Economics places entrepreneurship as the driving force of economic phenomena $[21,22,60,61]$. The term entrepreneurship "as used by [economic] theory means acting man exclusively seen from the aspect of the uncertainty inherent in every action" [20]. In this broad sense, all human action implies entrepreneurship as a chosen behavior in an open-ended evolving process in which the actor devises in advance based on a preconceived project. People continually make decisions that rely on their subjective interpretation of past and present data and apply judgment to imagine the uncertain future $[62,63]$. The judgment is a subjective assessment of the suitability of the means that the actor owns and controls to achieve his ends. While the ends are human problems that people judge worth solving, the means are the tangible or intangible goods that people judge useful to achieve the most valued ends as solving human problems. What the actor judges as a human problem (choice of ends worth solving) and how to solve it (choice of means) depend on a dynamic process of classification of stimuli in cognitive maps, incorporated in memory through judgments on the fly according to the environmental contexts that produce the phenomenological experiences [64]. The set of human problems and the possible resources and strategies to solve them are unknown ex ante.

The concept of entrepreneurship implies that the actor has private property rights over their body and mind $[65,66]$. When the actor judges an unsatisfactory situation in the environment worth improving, they create information on the fly in their mind. Entrepreneurship is inherently creative, especially through "learning by doing" and "learning by seeing" as a kind of filter for the cognitive impulses of the environment. The actor has private property over the results of their entrepreneurial creativity because they judge what a human problem is and how to solve it. However, people have infinite human problems and scarce means for solving them. People also do not have the cognitive skills or stability to independently solve all their human problems. People realize that the best way to solve their problems is by cooperating with others: a mutually beneficial exchange implies that both parties value what they receive more than what they give in return. In other words, people judge that to solve their human problems, they must direct their mind first to solve the problems of others, developing the specialization and division of knowledge (well known as the division of labor). This explains why entrepreneurship cultivates the market process as voluntary exchanges of private property rights $[67,68]$. The market process is the consequence of mutual recognition of the private property rights of the parties, forming the price system as historical exchange relations in monetary units. Prices are signals about people's judgments, participating in the market or refraining from doing so, making feasible the economic calculation to estimate the anticipated future results of the different action plans. The economic calculation consists of expectations and accounting, which saves scarce resources [69]. Specifically, the profit and loss accounts are the entrepreneurial returns from solving human problems as a compass on what to produce (consume), how to produce (consume), and what quantity and price. 
Once price signals are transmitted in the market process, entrepreneurship cultivates social coordination, as suppliers and demanders solve human problems. The coordinating effect does not refer to the static "equilibrium" of the fictitious supply and demand curves; it refers to entrepreneurial gains and losses through economic calculation. If people are sovereign of their private property rights, the market tends to discipline and coordinate action plans, reducing ignorance to identify socially valued human problems and solve them creatively [21]. Cognitive impulses can also serve as stimuli, creating other impulses on the fly, which act as intermediaries between the supply and demand dispositions of the market. These stimuli lead to higher orders of classification and an enormous increase in the complexity of the economic system [70,71]. The cognitive feedback of the brand-new market conditions serves as a platform for subsequent trials to identify and solve increasingly complex human problems. In this sense, economic development is the entrepreneurial widening range of alternatives open to people as more and better solutions to human problems, including the prosaic (more and better food and clothing alternatives) to the deeper (more and better work, housing, education, health, and security alternatives, along with better care of the environment) [72,73]. The more solutions open to people a society has, the more developed it will be. Accordingly, there can only be economic development if coordinating the supply and demand solves human problems. This process is dynamically efficient because profits (losses) depend on how well (bad) entrepreneurs consistently meet the needs of others.

In this sense, the boost theory is a developing research program within Austrian Economics, which explains how the institutional environment empowers entrepreneurship to cultivate economic development [74]. From the boost theory standard, economic development is only possible when (1) private property rights are secure in an organized society through contractual ties, and (2) aggressions on private property and the violation of contracts are punished $[75,76]$. An institutional environment conducive to secure private property rights empowers entrepreneurial confidence and cognitive stability to cultivate economic development, reducing transaction costs and uncertainty. Alternatively, an institutional environment hostile to private property raises confiscation risks: the possibility of people being deprived of their property. Some examples of confiscation risks are lack of public order (i.e., crime and street violence) and legal equality (the rule of law), institutional and public financial instability, unstable monetary conditions, and confiscatory policies of tax hikes and regulations [77]. The fundamental principle is that the higher risks of confiscation tend to increase political and economic uncertainty and, consequently, the cognitive instability of entrepreneurship. It is usually anticipated discoordination between the supply of demand for solutions to human problems and decreasing people's well-being. The higher confiscation risk of private property means restricting entrepreneurship in some economic system areas [21]. If there is no free entrepreneurship, the market process is restricted because there are no voluntary exchanges of private property rights. Every step away from private property rights is a step away from saving resources. As a result, the price system and economic calculation will be impossible in restricted areas, generating a dynamically inefficient process of social incoordination [78-81].

\subsubsection{The Boost Theory: The Psychological Point of View}

From the boost theory, economic development is based on psychological empowerment, defined as the self-confidence in one's abilities, capacities, and judgment to face life's challenges and thrive and the willingness to act accordingly [82]. Empowerment refers to the attitude that allows entrepreneurs to have a positive but realistic judgment of their abilities to identify and solve human problems. How does psychological empowerment emerge? Entrepreneurs face a natural environment (e.g., climatic conditions, geophysics, natural disasters, flora and fauna, life cycle, and diseases) and a social or institutional environment, defined as "the humanly devised constraints that structure political, economic and social interaction. They consist of both informal constraints (sanctions, taboos, customs, traditions, and codes of conduct), and formal rules (constitutions, laws, property 
rights)" [83]. However, the most significant determinants of empowerment are "people's economic attitudes, their social institutions and political arrangements, and to a much lesser extent natural resources and external market opportunities" [84]. The institutional environment arises to face the restrictions of the natural environment on people, which implies human problems to be solved with less uncertainty and transaction costs. The institutional environment is crucial for the self-confidence of entrepreneurs, particularly in poor countries. There is a relationship between secure private property rights and psychological empowerment $[85,86]$. When institutions secure private property rights, entrepreneurs are on the way to developing self-confidence and judgments on the fly, receiving a solid base to compete in the process of social coordination.

Although empowered entrepreneurs may have unrealistic expectations, they remain self-confident when some of their expectations are not met. Self-confident entrepreneurs are willing to risk the disapproval of others because they generally offer alternatives open to people under uncertainty. These beliefs are the basis of reducing ignorance on the fly and the origin of people's judgment $[87,88]$. Expectations determine the actor's judgment on the fly as the ability to react to new ideas, plans, or projects that promise profits. Self-confidence is not necessarily a general characteristic that permeates all aspects of an entrepreneur's life. Typically, entrepreneurs should have some areas of their lives in which they feel confident, for example, accounting, finance, human resources, sales, and marketing, while at the same time they should not feel confident at all in other areas, for example, increasing some of the confiscation risks to private property rights through coercive state interventionism. If institutions are excessively critical or hostile to private property rights or paternalistic and discourage movements towards entrepreneurship independence, people may believe that they are incapable, inadequate, or inferior to the political decision-makers. When entrepreneurs judge the higher risks of confiscation to their productive activity, they become less empowered and depend excessively on the ups and downs of political decision-making to survive in an environment of higher political and economic uncertainty [89]. Consider an institutional environment of lack of public order and legal inequality. If this is the case, entrepreneurs tend to avoid taking risks because they fear losing their investments at the hands of criminals or the arbitrariness of political decision-making, weakening and disregarding promises of profit as more restricted identification and solution of human problems $[90,91]$.

\subsubsection{Empowering Economic Development}

Figure 1 shows the chain of causality on how the boost theory's economic and psychological points of view complement and reinforces each other to explain the entrepreneurial process of economic development. The essential point is that the institutional environment concerns people's judgment of which human problems are worthwhile and the solution that promises profit. People's judgment creates knowledge, providing meaning to the cognitive impulses on the fly from the natural and social environment. The more people firmly believe that economic outcomes are highly dependent on their entrepreneurship (rather than external factors such as luck and confiscation risks), and the more they believe they can carry out their action plans successfully, the higher their self-confidence for learning by doing and learning by seeing. Although empirical psychological studies have shown that entrepreneurs have a high sense of internal control and personal efficacy, the meaning of the judgment on effectiveness in identifying and solving human problems explains entrepreneurship [92-94]. As a state of mind associated with cognitive readiness, judgment is necessary for learning because it allows the unsuspecting learner to extract and develop knowledge about the promises of profit from their environment, sometimes without prior intention to learn. 


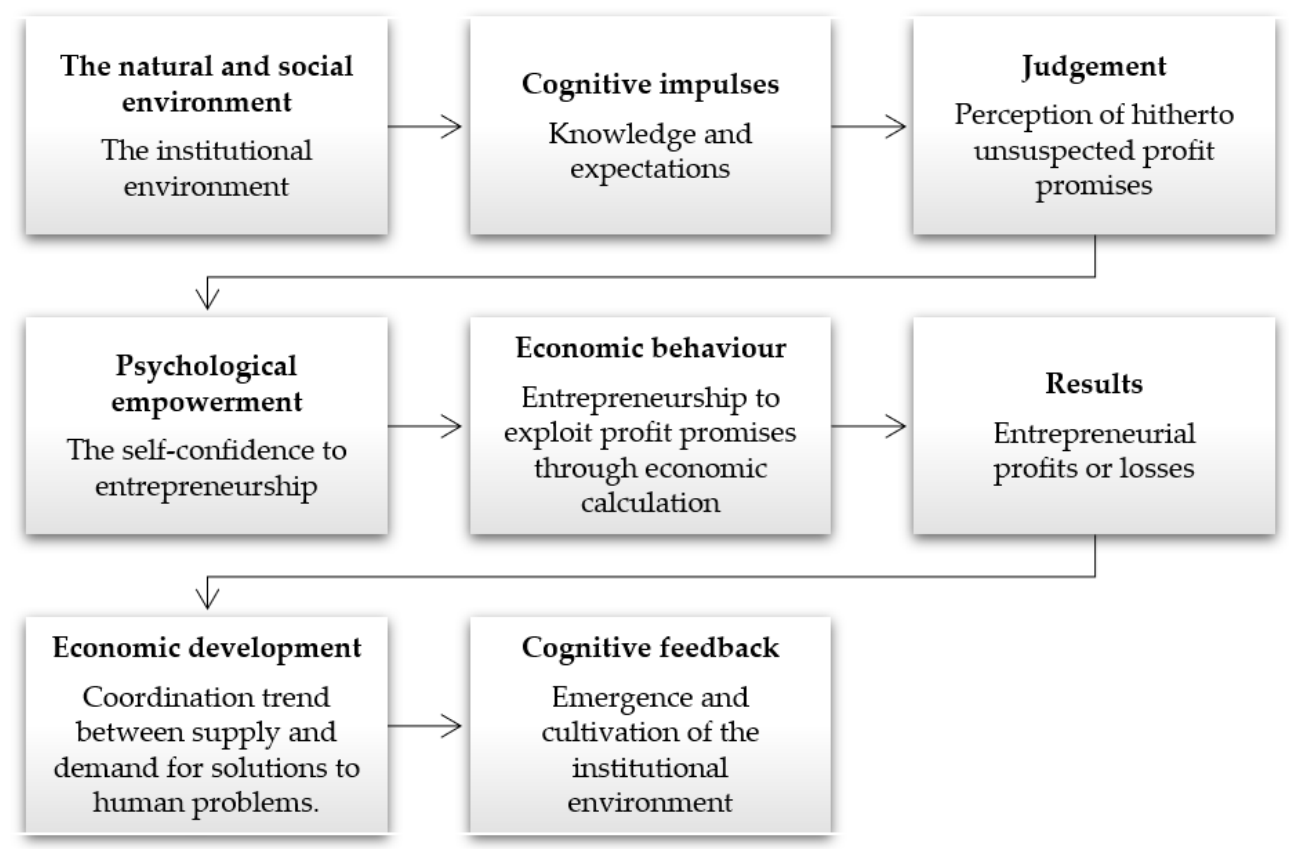

Figure 1. The boost theory's economic and psychological point of view. Own elaboration.

The institutional environment conducive to secure private property rights is a necessary and sufficient condition to cultivate economic development $[21,22,60]$. It is necessary because private property rights empower self-confidence and entrepreneurship in an economy without the confiscation risks. It is also sufficient because the physical and legal security environment empowers savings, investment, and mutually beneficial exchanges on the fly. Private property rights cultivate economic behavior through empowering the entrepreneurial market process, exploiting promises of profit as more and better solutions to human problems that are increasingly open to people. Empowering entrepreneurial competition cultivates economic development because it disciplines the reputation of the participants, coordinating the supply and demand for solutions to human problems through the price system and economic calculation. The resulting market conditions provide the cognitive feedback for the emergence and cultivation of evolutionary social institutions (i.e., language, moral standards, law, market) to deal with uncertainty through increasingly complex solutions to human problems [95].

The empirical evidence shows the cognitive feedback between the institutional environment, self-confidence for entrepreneurship and economic development [96-100]. If the smallest minority is assumed to be the individual, those who deny the private property rights of individuals cannot also claim to be defenders of minorities. Some cognitive biases are unlikely to change because they benefit the group in power (members of the majority group). In such cases, there should be legislation protecting the private property rights of minorities. Secure private property rights have fostered massive reductions in transportation and communication costs over the last half-century, providing the basis for the remarkable increase in economic development and incomes of all the world. As people have an environment of secure private property rights, the extent to which people perceive that they have a free choice has increased, leading to higher levels of happiness and human development. The empirical bias is toward highly decentralized political decision-making systems to empower entrepreneurship to widen people's access to more and better solutions to human problems, and against centralized political decision-making systems that steer default options in society.

\subsection{Steering or Empowering Decision-Making}

The previous sections reviewed two different approaches to behavioral development economics. On the one hand, nudge theory consists of a new form of paternalism, built on 
behavioral economics evidence that entrepreneurship is affected by cognitive biases. Behavioral paternalists argue that policies to correct these biases could result in better decisionmaking and well-being. On the other hand, the boost theory consists of a framework based on how the institutional environment empowers entrepreneurship and cultivates economic development, challenging the nudge theory's core argument. If cognitive biases can justify paternalism, then paternalists should coercively intervene in all areas of human life. The growing list of cognitive biases serves as a "surprise bag" of deviations from "rationality" (i.e., they do not make errors) [101-103]. However, the deviations indicate judgments that differ from what economists have historically assumed. Yet, why? It is seldom explained that rationality is a unique and technical concept created by mathematical economists to build models in static equilibrium situations, where the psychological composition of ends and means are given. If paternalists assume that they know people's "true" judgments, is it reasonable to take at face value the assumption that political decision-makers know the people's ends and means in ways that protect them from cognitive biases? Why should coercive state interventionism steer entrepreneurship?

Table 1 shows the controversy in behavioral development economics around the steering and empowering criteria on cognitive biases, the institutional environment to face such biases, and how construction of on-the-fly judgments works. First, the concept of cognitive bias for decision-making psychology is the starting point for both steering and empowering criteria [104]. The steering criteria argue that, as behavioral findings show, contrary to the equilibrium models used by mathematical economists who treat people as entirely rational, real people are not wholly rational. It follows that decision-making psychology can produce suboptimal outcomes because people can be irrational, quasirational, or possess limited rationality due to systematic cognitive biases in the economic way of thinking. Thus, the more modern form of paternalism assumes that people usually make decisions that are not good. It is treated as if any deviation from what paternalists denominate "true" judgments lacks rationality or some cognitive bias [105]. However, the paternalistic ideal is paradoxical. The political decision-makers are themselves people and, therefore, have cognitive biases! If cognitive biases afflict all people, political decisionmakers should explain why they do not have such biases. They do not explain it because they cannot. If they recognize that they too have cognitive biases, their whole model will be crumbled. In this regard, steering an architecture of choices to approximate people's 'true' judgments implies intellectual naivety, dictatorial arrogance, or both.

Furthermore, the empowering criteria reply that the psychology of decision-making is always rational. Entrepreneurship means judging human problems ex ante with the promise of solving them and obtaining ex post profits [106,107]. An action plan is driven by the promise of profit based on the actor's knowledge when undertaking it. The actor can judge ex-post that he makes an error in the choice of means to solve a human problem, that is, the subjective costs exceed the expected profits and, therefore, incur losses. If the means are inconsistent with the ends pursued, the result will not be expected. An inappropriate action may be contrary to the purpose, but it is rational because it is the outcome of reasoned deliberation by the actor, although defective and ineffective, to achieve a defined end. Thus, an irrational event is incompatible with entrepreneurship as the purposeful human action of any individual always constantly chooses his ends and means. Irrationality corresponds to involuntary reactions to external stimuli from the world of natural sciences. It implies that calling entrepreneurship irrational is arbitrary.

Second, the steering criteria neglect the comparative perspective of the institutional environment to cultivate economic development $[108,109]$. If there is an objective way to behave, and if people are not behaving that way, if they are not maximizing their life, that is somehow an irrational decision based on cognitive biases. A simple solution is to change the architecture of choice. Paternalists usually focus their research on designing coercive state interventions to steer people's decision-making through default rules $[110,111]$. However, the empowering criteria reply that before discussing the public policy itself and whether the architecture of choice can be calibrated fittingly, the behavioral economist should 
ask: where does this assumption come from that people should be calibrated? There are two senses in which the steering criteria see human beings as puppets. One is to control them and make sure they do what the paternalist judge should be doing, acting according to their true judgments. It also makes them the same puppets or cartoons as mathematical economics, conceiving people as neoclassical rational agents. The steering maxim is "we press you for your good", providing "the most beneficial outcome for all involved". However, as we ignore what we ignore and modern computing cannot save us from it, public policies will be inexorably arbitrary. The impossibility of economic calculation will arise in institutional environments hostile to private property rights $[81,112]$ The empowering criteria place the comparative perspective of the institutional environment as essential for cultivating economic development. There is a big difference between, on the one hand, a competitive market process with low confiscation risks in which many architects make decisions induced by the forces of supply and demand and, on the other hand, a market intervened by the confiscation policy, designed explicitly to steer people into the same architecture of choice.

Table 1. The key criticisms of the steering criterion from the empowerment criterion for behavioral development economics. Own elaboration.

\begin{tabular}{cc}
\hline Key Points & Steering Criteria \\
\hline & Decision-making psychology can produce \\
suboptimal outcomes because people can be \\
irrational, quasi-rational, or possess limited \\
rognitive biases in & rionality due to systematic cognitive biases in \\
decision & the economic way of thinking. Any deviation \\
-making psychology & from what paternalists denominate "true" \\
judgments lacks rationality or \\
some cognitive bias.
\end{tabular}

The role of the institutional environment in political decision-making
The steering criteria neglect the comparative perspective of the institutional environment to cultivate economic development. Paternalists usually focus their research on designing coercive state interventions to steer people's decision-making through default rules.

\section{Empowering Criteria}

The paternalistic ideal is paradoxical. The political decision-makers are themselves people and, therefore, have cognitive biases! If they recognize that they too have cognitive biases, their whole model will crumble. Steering an architecture of choices to approximate people's 'true' judgments implies intellectual naivety, dictatorial arrogance, or both.

The empowering criteria place the comparative perspective of the institutional environment as essential for economic development. There is a

big difference between, on the one hand, a competitive market process with low confiscation risks and, on the other hand, a market intervened by the confiscation policy.

Judgments emerge on the fly as a process of increasing classification that generates

The steering criteria do not consider how judgments construction on the fly works. If cognitive biases can be enough to justify coercive state interventionism for people's good, behavioral economists have not adequately addressed how the mind works. phenomenological experience, expectations, and learning by seeing and doing. Like two snowflakes, no two individuals are identical. Each person's mental storage of classification is subjected to a continuous gradual change according to their judgments under uncertainty.
The role of freedom in economics
Finally, the steering criteria do not consider how construction of on-the-fly judgments works. If cognitive biases can be enough to justify coercive state interventionism for people's physical or moral good, behavioral economists have not adequately addressed how the mind works $[113,114]$. They have challenged the idea that people are necessarily acting according to their subjective judgments, saying: "People make errors, and that means there is room to step in to try to correct those current and potential errors". Even if people behave irrationally due to cognitive biases, that does not give the analyst or the politician the right to determine which lifestyle is correct. Likewise, political decision-makers also have cognitive biases, so it is logically impossible for them to know the ends and means of other people. Suppose most confiscation policies tend to be standardized according to the type of person, firm, or industry. If this is the case, paternalists who suffer from cognitive biases must solve the problem of the heterogeneity of people's subjective judgments. How 
do the true judgments of people differ? How do biases differ? How do the self-correction policies differ? When paternalists intervene by steering some people, will they harm other people? How are paternalists going to weigh those profits and losses against each other? Political decision-makers' knowledge problem means that it is doubtful that paternalists will answer any of those questions.

How are judgments built? The empowering criteria state that people's subjective judgments are built on the fly in a dynamic classification process and feedback with the natural and social environment. Following theoretical psychology, there are two different orders: (1) a physical order, which is manifested through the natural sciences, and (2) a sensory order, which people experience through the senses $[115,116]$. The sensory order involves a chain of events in an organism, which is somehow related to the physical order in the external and internal environment that the actor experiences. The central nervous system is a giant mechanism for classifying cognitive impulses due to combinations of complex systems of neural connections. Receptor organs sensitive to stimuli tend to become excited, sending a sequence of sensory impulses through the massive network of interconnected neurons. Each stimulus causes initial sensory impulses and then subsequent repetitions of them, and these form patterns between the increasingly complex classification levels that constitute the neural network and people's judgments [117]. These judgments emerge on the fly as a process of increasing classification that generates phenomenological experience, expectations, and learning by seeing and doing. Like two snowflakes, no two individuals are identical. Each person's mental storage of classification is subjected to a continuous gradual change according to their judgments under uncertainty. It is inevitable to recognize that libertarian etiquette paternalism seeks to steer people according to the interests of political decision-makers. If there are no "optimal" behaviors, there is no freedom to choose when experts steer people's possibilities.

\section{Discussion and Proposals}

Poverty and extreme poverty in Latin America reached levels in 2020 that have not been observed in the last 20 years, amid a worsening of inequality indices and employment and participation rates for working, especially in women, due to the COVID-19 pandemic and despite the emergency social protection measures those countries have adopted to stop it $[118,119]$. Due to the powerful economic recession in Latin America, which will register a drop in GDP of $-7.7 \%$, it is estimated that in 2020 the extreme poverty rate will stand at $12.5 \%$, and the poverty rate will reach $33.7 \%$ of the population [120]. This means that the total number of poor people reached 209 million at the end of 2020, 22 million more than the previous year. Of this total, 78 million people found themselves in extreme poverty, 8 million more than in 2019 [120]. Faced with this situation, behavioral development economics explains that living in poverty can exacerbate cognitive biases and irrational behaviors, deepening poverty in a vicious cycle of lack of money and frustration. Nudge theory argues that coercive state interventionism is fundamental to steer the decisionmaking of the poor towards ends that improve their material and spiritual condition. Steering consists of default rules defined by political decision-makers to protect the poor's cognitive biases and irrational behavior.

In public policy, the nudge theory combines the psychological approach of cognitive biases and the theory of market failures, which is understood as a situation that happens when the market is unable to optimally correct the poor's lack of rationality in their economic behaviors [121,122]. The nudge theory approach to public policy begins with the model of perfect competition: a static situation in which there are numerous suppliers and demanders, in addition to an equilibrium price and quantity. The model's main characteristics are that the agents are price-accepting (i.e., they do not compete in the real sense of the word) and have perfect information, the goods offered are homogeneous, and there is an absence of technological or legal barriers to entry or exit in the market. Since the model's assumptions do not happen, behavioral economists generally complain of failures when the market cannot allocate resources "optimally as predicted by the model". People 
are irrational, quasi-rational, or have limited rationality in a market failure situation. Thus, cognitive biases are detrimental to their well-being. If the model assumes that information about the ends and means of the poor is given to political decision-makers, behavioral economists use it to recommend steering people out of poverty. However, what does the boost theory say about market failures? What are the proposals to correct them from the empowering point of view?

As explained in the previous section, the nudge theory has three insurmountable problems due to paternalistic cognitive biases: (1) the nudge theory ignores the paternalistic cognitive biases, (2) it neglects the comparative perspective of the institutional environment in the face of such biases, and (3) does not consider how the construction of judgments works on the fly. Fundamentally, the logic of human problem solving is a dynamic process of rationalization or reconstruction of situations in the natural and social environment. When people talk about a human problem, it is almost always done retrospectively, but an exact solution cannot be determined in advance $[123,124]$. Because different people face different human problems, there is a division or distribution of knowledge in society. The nature of people's judgments communicated in society is subjective. There is no limit to the enrichment of the social stock of knowledge, except for the practically unexplored frontiers of the nudge theory on how an institutional environment hostile to private property rights makes the genuine manifestation of people's judgments impossible in the market process (i.e., voluntary exchanges of private property rights). Steering a libertarian or socialist paternalism is deficient and will almost inevitably cause the analyst to err in applying public policy, distorting the price system and making economic calculation impossible. Therefore, any idea of a final equilibrium state of knowledge must be expelled, along with the main conclusions of the nudge theory approach to market failures and public policy proposals [125].

Suppose the case of information asymmetry, understood as a market situation in which one party has more information than the other. Suppliers tend to have more information than consumers: they know better what they sell than those who buy it. When one of the two parties has more information than the other, cognitive biases disrupt the market equilibrium. While the party with more information has privileged information, the buyer could not make the best decision because of "uncertainty" or "imperfect knowledge". One manifestation of information asymmetry is adverse selection: the more informed party will be willing to trade precisely when it is least advantageous to its less informed counterpart. It increases the possibility of fraud and mistrust between individuals, which reduces cooperation and social welfare. Political decision-makers should intervene in the economy to eliminate information asymmetries, steering default rules on an exchange between two people or groups. Information about the ends and means most beneficial to the rest of the people is somehow more available to the paternalist than to the participants in voluntary exchanges of private property rights.

From the boost theory, information asymmetry and adverse selection concepts are irrelevant in a dynamic economy. All exchanges happen due to the "inequality" of judgments between individuals, so information asymmetries are inherent in real-life dynamics [126,127]. As a process of identifying and solving human problems, entrepreneurship involves the plurality of competing ends and means. Precisely, this plurality of judgments cultivates the division of knowledge and social cooperation [128]. Given that information equality is impossible in a dynamic society, the steering's claim to remove information asymmetry and adverse selection through coercive state interventionism is absurd. The paradox is evident: market failure theorists assume that people have problems of information asymmetry and adverse selection; however, in turn, they argue that the state, also made up of individuals, is the bearer of privileged knowledge! If the differences in information turn into reputational problems, the solution will go through the legal protection of private property rights, legal equality, and cultural change towards the rejection of fraud, theft, murder, or censorship. If market players cannot know the "social optimum" is, there are epistemological reasons to question whether political decision-makers can 
efficiently coordinate action plans. When the state intervenes in the market, it increases confiscation risks, restricting entrepreneurship and economic development. Moreover, if it does not intervene, it does not obtain any information. These findings also fit other market failure cases, such as monopoly, externalities, and public goods, which have recently been addressed in other works [129-132].

The boost theory explains market failures as "coordination problems" between supply and demand of the widening range of alternatives open to people. They are the errors of entrepreneurial judgment to identify and solve human problems: the means chosen ex-ante were not adequate to achieve the end ex-post. It is part of the psychological learning process of human life, which is also influenced by institutional and technological barriers to entrepreneurship. Some proposals are essential to cultivating economic development in a post-COVID-19 world. Specifically, proposals aimed at empowering entrepreneurship to solve coordination problems should include: (1) constitutional and institutional protection of private property rights (safeguard the freedom of entrepreneurship against the omnipotent, meddlesome, and dispensing governments of subsidies and privileges, whose coercion is the essence of poverty and underdevelopment); (2) legal equality (all people should have the same dignity, rights, and duties); (3) a legal system of dissuasive sanctions against confiscation risks (promoting the entrepreneurial reputation and social cooperation); and (4) a cultural change through economic and financial education on the ethics of private property, the entrepreneurial function, and saving (if you want to change the world, change yourself first!) [133-135].

Consider the case of the COVID-19 pandemic, where self-care is a matter of personal and social responsibility (i.e., empathy with others). The institutional environment favorable to secure private property empowers self-confidence and cognitive stability for anyone in the real world, fostering a culture of self-care due to respect for the private property rights of others. In other words, cultural change toward responsibility allows the independence of people's judgment from political decision-makers. For instance, the Swedish strategy against COVID-19 has so far yielded a surprising result: voluntary measures of empowerment through a culture of self-care can achieve very similar results to coercive measures of steering a set of default options [136]. Thus, institutions can reduce, but not eliminate, cognitive biases and uncertainty to narrow the range of possible actions of some specific orientation points for entrepreneurship that make economic development possible. It is a process of social coordination of patterns when the action plans possibilities are open, allowing spontaneity or novelty. The social coordination of patterns recognizes the exclusivity of the on-the-fly judgments that operate in economic activities.

Furthermore, the boost theory incorporates and overcomes the behavioral development economics consensus on equilibrium-allocative efficiency [137]. The risk of paternalistic cognitive biases is more damaging when "experts" enjoy a monopoly of violence through state interventionism to steer people rather than empower them. Even when state power steers people by default rules, the legal monopoly on violence could reduce the autonomy of the governed in a dynamically inefficient process. Suppose entrepreneurship is restricted in certain areas. In that case, the dynamic efficiency of the social coordination process is distorted, and people will not even be conscious of all the profit promises that would have arisen in the absence of coercion. Coordination cannot be resolved under the static given-resource framework of the steering point of view. People are always creative, and state legislations and commands should not impede the free exercise of entrepreneurship. Hence the vicious cycle of poverty results from factors exogenous to the market process, such as legal or institutional barriers to stifle entrepreneurship. If confiscation risks negatively affect entrepreneurship and economic development, reality ruins any paternalistic claims for indicative or central planning. Thus, the boost theory of Austrian economics renders the paternalistic desire to steer people ineffective. Decentralized entrepreneurship is the only procedure discovered by economics that deals with the universal presence of ignorance and uncertainty. Moreover, free entrepreneurship cultivates the highest degree of social coordination "humanly possible", developing dynamic efficiency in solving in- 
creasingly complex human problems. This is how the institutional empowerment of the entrepreneurial market process turns into sustained reductions in confiscation risks to escape paternalism.

\section{Conclusions}

Behavioral development economics explains that poverty can directly affect cognitive function and economic behaviors, potentially exacerbating cognitive biases and deepening poverty. It is first assumed that people have cognitive biases, but then it is assumed that political decision-makers are somehow exempt from these biases. As a result, political decision-makers may know the "real" ends and means of the poor. Following this hypothesis, nudge theory recommends steering people towards an architecture of given choices in any situation through coercive state interventionism. There is a large body of work on how political decision-makers can design default rules to defeat the cognitive biases of the poor in libertarian paternalism. However, this article demonstrated that the fundamental hypothesis of behavioral development economics has an insurmountable error: political decision-makers are also people, therefore, they also have paternalistic cognitive biases. The error's root is to have neglected the comparative perspective of the institutional environment in the face of such biases and not considered how the construction of judgments on the fly works. As the article shows, behavioral development economics is based on static and hypothetic equilibrium situations, where ends and means are given, which can be known through experiments or quasi-experiments.

The article explained the principles of boost theory developed by Austrian economics to overcome deficiencies noted above within behavioral development economics. The boost theory consists of a psychological and economic analysis of entrepreneurship as the driving force behind economic development. The contribution includes analyzing how judgments are built on the fly and how the institutional environment can empower entrepreneurship to cultivate economic development. The points of view of empowerment and steering were confronted with glimpsing their main theoretical and practical differences to overcome the erroneous hypothesis on which the nudge theory is based. It was also discussed why the boost theory understands the theory of market failures as a theory of coordination problems, which offers novel conclusions to escape poverty and paternalism. General guidelines for public policies were proposed to reduce the risks of confiscation to entrepreneurship, which are the essential cause of poverty and underdevelopment. Political decision-makers can no longer have a good background in economics if they are not familiar with the principles of how real-life economics works and how the novel findings of boost theory can reduce poverty.

The abuse of modeling the real economic world without real-life economics and related social science knowledge would make economists have a fatal conceit [138]. The scope of understanding human action is much more complex than making social engineering and central planning. Thus, the boost theory offers a robust framework for further theoretical and empirical research on how an institutional setting influences empowering entrepreneurship and cultivates economic development. Although there is no hypothesis testing, this article still contains enough theoretical discussion to allow readers and other interested parties to gain theoretical insights before further empirical testing of related behavioral phenomena. Further works should also explore the philosophical feasibility of a theoretical convergence between steering and empowering approaches for behavioral development economics.

Author Contributions: Conceptualization, V.I.E.; methodology, V.I.E. and W.H.W.; formal analysis, V.I.E., W.H.W. and J.H.d.S.; investigation, V.I.E., W.H.W. and J.H.d.S.; resources, V.I.E., W.H.W. and J.H.d.S.; writing — original draft preparation, V.I.E.; writing-review and editing, V.I.E., W.H.W. and J.H.d.S.; funding acquisition, V.I.E., W.H.W. and J.H.d.S. All authors have read and agreed to the published version of the manuscript.

Funding: This research received no external funding. 


\section{Institutional Review Board Statement: Not applicable.}

Informed Consent Statement: Not applicable.

Data Availability Statement: Not applicable.

Acknowledgments: For comments and criticism, the authors wish to thank the three anonymous referees. The usual caveat applies.

Conflicts of Interest: The authors declare no conflict of interest.

\section{References}

1. Thaler, R.H.; Sunstein, C.R. Libertarian paternalism. Am. Econ. Rev. 2003, 93, 175-179. [CrossRef]

2. Thaler, R.H.; Sunstein, C.R. Nudge: Improving Decisions about Health, Wealth, and Happiness; Yale University Press: New Haven, CT, USA, 2008

3. Hausman, D.M.; Welch, B. Debate: To nudge or not to nudge. J. Political Philos. 2010, 18, 123-136. [CrossRef]

4. Hansen, P.G. The definition of nudge and libertarian paternalism: Does the hand fit the glove? Eur. J. Risk Regul. 2016, 7, 155-174. [CrossRef]

5. Trout, J.D. Paternalism and cognitive bias. Law Philos. 2005, 24, 393-434. [CrossRef]

6. Börsch-Supan, A. Mind the gap: The effectiveness of incentives to boost retirement saving in Europe. OECD Econ. Stud. 2004, 39, 111-144.

7. World Health Organization. Obesity and Overweight. Factsheet No. 311. Geneva, Switzerland. 2021. Available online: https://www.who.int/news-room/fact-sheets/detail/obesity-and-overweight (accessed on 26 October 2021).

8. Kahneman, D.; Slovic, P.; Tversky, A. Judgment under Uncertainty: Heuristics and Biases; Cambridge University Press: New York, NY, USA, 1982.

9. Demeritt, A.; Hoff, K. The making of behavioral development economics. Hist. Political Econ. 2018, 50, 303-322. [CrossRef]

10. Kremer, M.; Rao, G.; Schilbach, F. Behavioral development economics. In Handbook of Behavioral Economics: Applications and Foundations 1; Douglas Bernheim, B., DellaVigna, S., Laibson, D., Eds.; North-Holland: New York, NY, USA, 2019; Volume 2, pp. 345-458.

11. Kahneman, D. Maps of Bounded Rationality: Psychology for Behavioral Economics. Am. Econ. Rev. 2003, 93, 1449-1475. [CrossRef]

12. Kahneman, D.; Tversky, A. Prospect theory: An analysis of decision under risk. Econometrica 1979, 47, 263-291. [CrossRef]

13. Tversky, A.; Kahneman, D. Advances in prospect theory: Cumulative representation of uncertainty. J. Risk Uncertain. 1992, 5, 297-323. [CrossRef]

14. Duflo, E. The economist as plumber. Am. Econ. Rev. 2017, 107, 1-26. [CrossRef]

15. Teal, J.; Kusev, P.; Heilman, R.; Martin, R.; Passanisi, A.; Pace, U. Problem Gambling 'Fuelled on the Fly'. Int. J. Environ. Res. Public Health 2021, 18, 8607. [CrossRef] [PubMed]

16. Martin, R.; Kusev, P.; Teal, J.; Baranova, V.; Rigal, B. Moral Decision Making: From Bentham to Veil of Ignorance via Perspective Taking Accessibility. Behav. Sci. 2021, 11, 66. [CrossRef] [PubMed]

17. Kusev, P.; Van Schaik, P.; Martin, R.; Hall, L.; Johansson, P. Preference reversals during risk elicitation. J. Exp. Psychol. Gen. 2020, 149, 585-589. [CrossRef] [PubMed]

18. Kusev, P.; van Schaik, P.; Ayton, P.; Dent, J.; Chater, N. Exaggerated risk: Prospect theory and probability weighting in risky choice. J. Exp. Psychol. Learn. Mem. Cogn. 2009, 35, 1487-1505. [CrossRef]

19. Huerta de Soto, J. The Austrian School: Market Order and Entrepreneurial Creativity; Edward Elgar: Northhampton, UK, 2008.

20. Mises, L. Human Action: A Treatise on Economics; Henry Regnery: Chicago, IL, USA, 1966.

21. Espinosa, V.I.; Alonso Neira, M.A.; Huerta de Soto, J. Principles of sustainable economic growth and development: A call to action in a post-COVID-19 world. Sustainability 2021, 13, 13126. [CrossRef]

22. Espinosa, V.I. Principios Modernos de Economía del Desarrollo: Teoría y Práctica; Unión Editorial: Madrid, Spain, In press.

23. Moyo, D. Dead Aid: Why Aid Is Not Working and How There Is a Better Way for Africa; The Penguin Press: New York, NY, USA, 2009.

24. Easterly, W. The Tyranny of Experts: Economists, Dictators, and the Forgotten Rights of the Poor; Basic Books: New York, NY, USA, 2014.

25. Backhouse, R.; Medema, S. On the definition of economics. J. Econ. Perspect. 2009, 23, 221-234. [CrossRef]

26. Mirowski, P.E. Physics and the marginalist revolution. Camb. J. Econ. 1984, 8, 361-379. [CrossRef]

27. Mirowski, P.E. More Heat than Light: Economics as Social Physics, Physics as Nature's Economics; Cambridge University Press: New York, NY, USA, 1989

28. Mirowski, P.E. The when, the how and the why of mathematical expression in the history of economic analysis. J. Econ. Perspect. 1991, 5, 145-157. [CrossRef]

29. Persky, J. The ethology of homo economicus. J. Econ. Perspect. 1995, 9, 221-231. [CrossRef]

30. Yamagishi, T.; Li, Y.; Takagishi, H.; Matsumoto, Y.; Kiyonari, T. In search of Homo economicus. Psychol. Sci. 2014, 25, 1699-1711. [CrossRef]

31. Backhouse, R.E. An empirical philosophy of economic theory. British J. Philos. Sci. 1995, 46, 111-121. [CrossRef]

32. Boettke, P.J.; Lopez, E.J. Austrian economics and public choice. Rev. Austrian Econ. 2002, 15, 111-119. [CrossRef] 
33. Alacevich, J. The Birth of Development Economics: Theories and Institutions. Hist. Political Econ. 2018, 50, 114-132. [CrossRef]

34. Alter, M. Carl Menger and Homo Oeconomicus: Some thoughts on Austrian theory and methodology. J. Econ. Issues 1982, 16, 149-160. [CrossRef]

35. Thaler, R.H. From homo economicus to homo sapiens. J. Econ. Perspect. 2000, 14, 133-141. [CrossRef]

36. Kahneman, D.; Tversky, A. Subjective probability: A judgment of representativeness. Cogn. Psychol. 1972, 3, 430-454. [CrossRef]

37. Tversky, A.; Kahneman, D. Judgment under uncertainty: Heuristics and biases. Science 1974, 185, 1124-1131. [CrossRef]

38. Hoff, K.; Joseph, E. Stiglitz. Equilibrium fictions. Am. Econ. Rev. 2010, 100, 141-146. [CrossRef]

39. Hoff, K.; Joseph, E. Stiglitz. Striving for balance in economics: Towards a theory of the social determination of behavior. J. Econ. Behav. Organ. 2016, 126, 25-57. [CrossRef]

40. Heukelom, F. Behavioral Economics: A History; Cambridge University Press: New York, NY, USA, 2014.

41. Thaler, R.H. Misbehaving: The Making of Behavioral Development Economics; W. W. Norton: New York, NY, USA, 2000.

42. Davis, J.B. Economics imperialism under the impact of psychology: The case of behavioral development economics. OEconomia 2013, 3, 119-138. [CrossRef]

43. Datta, S.; Mullainathan, S. Behavioral design: A new approach to development policy. Rev. Income Wealth 2014, 60, 7-35. [CrossRef]

44. Shah, A.K.; Zhao, J.; Mullainathan, S.; Shafir, E. Money in the mental lives of the poor. Soc. Cogn. 2018, 36, 4-19. [CrossRef]

45. Sharif, M.A.; Mogilner, C.; Hershfield, H.E. Having too little or too much time is linked to lower subjective well-being. J. Personal. Soc. Psychol. 2021, 121, 933-947. [CrossRef] [PubMed]

46. Shah, S.S.H.; Xinping, X.; Khan, M.A.; Harjan, S.A. Investor and manager overconfidence bias and firm value: Micro-level evidence from the Pakistan equity market. Int. J. Econ. Financ. Issues 2018, 8, 190-199.

47. Shah, S.S.H.; Khan, M.A.; Meyer, N.; Meyer, D.F.; Oláh, J. Does herding bias drive the firm value? Evidence from the Chinese equity market. Sustainability 2019, 11, 5583. [CrossRef]

48. Zhang, R.; Yang, X.; Li, N.; Khan, M.A. Herd behavior in venture capital market: Evidence from China. Mathematics 2021, 9 , 1509. [CrossRef]

49. Schmidt, A.T.; Engelen, B. The ethics of nudging: An overview. Philos. Compass 2020, 15, 1-13. [CrossRef]

50. Barnes, J.H., Jr. Cognitive biases and their impact on strategic planning. Strateg. Manag. J. 1984, 5, 129-137. [CrossRef]

51. Benartzi, S.; Beshears, J.; Milkman, K.L.; Sunstein, C.R.; Thaler, R.H.; Shankar, M.; Galing, S. Should governments invest more in nudging? Psychol. Sci. 2017, 28, 1041-1055. [CrossRef]

52. Sunstein, C. Why Nudge? The Politics of Libertarian Paternalism; Yale University Press: New Haven, CT, USA, 2014.

53. Bowles, S.; Kirman, A.; Sethi, R. Retrospectives: Friedrich Hayek and the market algorithm. J. Econ. Perspect. 2017, 31, 215-230. [CrossRef]

54. Devereaux, A.N. The nudge wars: A modern socialist calculation debate. Rev. Austrian Econ. 2019, 32, 139-158. [CrossRef]

55. Wilkinson, T.M. Nudging and manipulation. Political Stud. 2013, 61, 341-355. [CrossRef]

56. Horwitz, S. Behavioural economics: A virginia political economy perspective. Econ. Aff. 2016, 36, 273-281. [CrossRef]

57. Tasic, S. Are Regulators Rational? J. Des Econ. Et Des Etudes Hum. 2011, 17, Article 3. [CrossRef]

58. Hayek, F.A. The use of knowledge in society. Am. Econ. Rev. 1945, 35, 519-530.

59. Kirzner, I.M. The entrepreneurial market process-An exposition. South. Econ. J. 2017, 83, 855-868. [CrossRef]

60. Huerta de Soto, J. The Theory of Dynamic Efficiency; Routledge: London, UK; New York, NY, USA, 2009.

61. Foss, N.J.; Klein, P.G. Organizing Entrepreneurial Judgment: A New Approach to the Firm; Cambridge University Press: New York, NY, USA, 2012.

62. Foss, N.J.; Klein, P.G.; Lien, L.B.; Zellweger, T.; Zenger, T. Ownership competence. Strateg. Manag. J. 2021, 42, 302-328. [CrossRef]

63. Steele, G.R. Hayek's sensory order. Theory Psychol. 2002, 12, 387-409. [CrossRef]

64. Lewis, P. Emergent properties in the work of Friedrich Hayek. J. Econ. Behav. Organ. 2012, 82, 368-378. [CrossRef]

65. Harper, D.A. Property rights, entrepreneurship and coordination. J. Econ. Behav. Organ. 2013, 88, 62-77. [CrossRef]

66. Redford, A. Property rights, entrepreneurship, and economic development. Rev. Austrian Econ. 2020, 33, 139-161. [CrossRef]

67. Kirzner, I.M. Entrepreneurial discovery and the competitive market process: An Austrian approach. J. Econ. Lit. 1997, 35, 60-85.

68. Boettke, P.J. Entrepreneurship, and the entrepreneurial market process: Israel M. Kirzner and the two levels of analysis in spontaneous order studies. Rev. Austrian Econ. 2014, 27, 233-247. [CrossRef]

69. Piano, E.E.; Rouanet, L. Economic calculation and the organization of markets. Rev. Austrian Econ. 2020, 33, 331-348. [CrossRef]

70. Rosser, J.B. On the complexities of complex economic dynamics. J. Econ. Perspect. 1999, 13, 169-192. [CrossRef]

71. Rosser, J.B., Jr. Emergence and complexity in Austrian economics. J. Econ. Behav. Organ. 2012, 81, 122-128. [CrossRef]

72. Beinhocker, E.; Hanauer, N. Redefining capitalism. McKinsey Q. 2014, 3, 160-169.

73. Espinosa, V.I.; Wang, W.H.; Zhu, H. Israel Kirzner on dynamic efficiency and economic development. Procesos De Merc. 2020, 17, 283-310. [CrossRef]

74. Boettke, P.J.; Coyne, C.J. Entrepreneurship and development: Cause or consequence? Adv. Austrian Econ. 2003, 6, 67-87. [CrossRef]

75. Bjørnskov, C.; Foss, N. How strategic entrepreneurship and the institutional context drive economic growth. Strateg. Entrep. J. 2013, 7, 50-69. [CrossRef] 
76. Bjørnskov, C.; Foss, N.J. Institutions, entrepreneurship, and economic growth: What do we know and what do we still need to know? Acad. Manag. Perspect. 2016, 30, 292-315. [CrossRef]

77. Rothbard, M.N. Power and Market: Government and the Economy; Sheed Andrews and McMeel: Kansas City, KS, USA, 1977.

78. Espinosa, V.I. Salvador Allende's development policy: Lessons after 50 years. Econ. Aff. 2021, 41, 96-110. [CrossRef]

79. Espinosa, V.I. Ciberplanificación, propiedad privada y cálculo económico. Rev. De Econ. Inst. 2021, 23, 163-184. [CrossRef]

80. Wang, W.H.; Espinosa, V.I.; Peña-Ramos, J.A. Private Property Rights, Dynamic Efficiency and Economic Development: An Austrian Reply to Neo-Marxist Scholars Nieto and Mateo on Cyber-Communism and Market Process. Economies 2021, 9, 165. [CrossRef]

81. Huerta de Soto, J. Socialism, Economic Calculation and Entrepreneurship; Edward Elgar: Northampton, UK, 2010.

82. Zimmerman, M.A. Psychological empowerment: Issues and illustrations. Am. J. Community Psychol. 1995, 23, 581-599. [CrossRef] [PubMed]

83. North, D.C. Institutions. J. Econ. Perspect. 1991, 5, 97-112. [CrossRef]

84. Bauer, P.T. From Subsistence to Exchange and Other Essays; Princeton University Press: Princeton, NJ, USA, 2000.

85. Spreitzer, G.M. Social structural characteristics of psychological empowerment. Acad. Manag. J. 1996, 39, 483-504.

86. Harper, D.A. Foundations of Entrepreneurship and Economic Development; Routledge: New York, NY, USA, 2003.

87. Aimar, T. The curious destiny of a heterodoxy: The Austrian economic tradition. Rev. Austrian Econ. 2009, 22, 199-207. [CrossRef]

88. Aimar, T. The Economics of Ignorance and Coordination: Subjectivism and the Austrian School of Economics; Edward Elgar: New York, NY, USA, 2014.

89. Segal, G.; Borgia, D.; Schoenfeld, J. The motivation to become an entrepreneur. Int. J. Entrep. Behav. Res. 2005, 11, 42-57. [CrossRef]

90. Gadon, L.; Johnstone, L.; Cooke, D. Situational variables and institutional violence: A systematic review of the literature. Clin. Psychol. Rev. 2006, 26, 515-534. [CrossRef]

91. Ikeda, S. Dynamics of interventionism. In Oxford Handbook of Austrian Economics; Boettke, P.J., Coyne, C.J., Eds.; Oxford University Press: New York, NY, USA, 2015.

92. Frese, M.; Gielnik, M.M. The psychology of entrepreneurship. Annu. Rev. Organ. Psychol. Organ. Behav. 2014, 1, 413-438. [CrossRef]

93. Cropley, D.H.; Cropley, A.J. The Psychology of Innovation in Organizations; Cambridge University Press: New York, NY, USA, 2015.

94. Gorgievski, M.J.; Stephan, U. Advancing the psychology of entrepreneurship: A review of the psychological literature and an introduction. Appl. Psychol. 2016, 65, 437-468. [CrossRef]

95. Meseguer, C.M. La Teoria Evolutiva de las Instituciones: La Perspectiva Austriaca; Unidad Editorial: Madrid, Spain, 2006.

96. Boettke, P.; Subrick, J.R. Rule of law, development, and human capabilities. Supreme Court Econ. Rev. 2003, 10, 109-126. [CrossRef]

97. Gwartney, J.D.; Holcombe, R.G.; Lawson, R.A. Economic freedom, institutional quality, and cross-country differences in income and growth. Cato J. 2003, 24, 205-233.

98. Inglehart, R.; Foa, R.; Peterson, C.; Welzel, C. Development, freedom, and rising happiness: A global perspective (1981-2007). Perspect. Psychol. Sci. 2008, 3, 264-285. [CrossRef]

99. Connors, J.; Gwartney, J.D.; Montesinos, H.M. The transportation-communication revolution: 50 years of dramatic change in economic development. Cato J. 2020, 40, 153-198.

100. Wang, W.H.; Moreno-Casas, V.; Huerta de Soto, J. A free-market environmentalist transition toward renewable energy: The cases of Germany, Denmark, and the United Kingdom. Energies 2021, 14, 4659. [CrossRef]

101. Rizzo, M.J.; Whitman, G. Escaping Paternalism: Rationality, Behavioral Economics, and Public Policy; Cambridge University Press: New York, NY, USA, 2019.

102. Espinosa, V.I.; Carreiro, Ó.R. Old and new development economics: A reassessment of objectives. Q. J. Austrian Econ. 2021, 24, 254-285. [CrossRef]

103. Espinosa, V. Epistemological problems of development economics. Procesos De Merc. 2020, 17, 55-93. [CrossRef]

104. Hertwig, R.; Ryall, M.D. Nudge versus boost: Agency dynamics under libertarian paternalism. Econ. J. 2020, $130,1384-1415$. [CrossRef]

105. Schnellenbach, J. A constitutional economics perspective on soft paternalism. Kyklos 2016, 69, 135-156. [CrossRef]

106. Langlois, R.N. Knowledge and rationality in the Austrian school: An analytical survey. East. Econ. J. 1985, 11, 309-330.

107. Rizzo, M.J. The problem of rationality: Austrian economics between classical behaviorism and behavioral economics. In Oxford Handbook of Austrian Economics; Boettke, P.J., Coyne, C.J., Eds.; Oxford University Press: New York, NY, USA, 2015.

108. Jolls, C.; Sunstein, C.R.; Thaler, R. A behavioral approach to law and economics. Stanf. Law Rev. 1997, 50, 1471-1550. [CrossRef]

109. Sunstein, C.R. Deciding by default. Univ. Pa. Law Rev. 2013, 162, 1-57.

110. Wilkinson, T.M. Counter-Manipulation and Health Promotion. Public Health Ethics 2017, 10, 257-266. [CrossRef]

111. Guala, F.; Mittone, L. A political justification of nudging. Rev. Philos. Psychol. 2015, 6, 385-395. [CrossRef]

112. Halpern, D.; Sanders, M. Nudging by government: Progress, impact, \& lessons learned. Behav. Sci. Policy 2016, 2, $52-65$.

113. Hauser, O.P.; Gino, F.; Norton, M.I. Budging beliefs, nudging behaviour. Mind Soc. 2018, 17, 15-26. [CrossRef]

114. Hayek, F.A. The Sensory Order: An Inquiry into the Foundations of Theoretical Psychology; University of Chicago Press: Chicago, IL, USA, 1952.

115. Caldwell, B. Some reflections on F. A. Hayek's the sensory order. J. Bioeconomics 2004, 6, 239-254. [CrossRef]

116. Fuster, J.M. Hayek in today's cognitive neuroscience. Adv. Austrian Econ. 2011, 15, 3-11. 
117. McQuade, T.J.; Butos, W.N. The sensory order and other adaptive classifying systems. J. Bioeconomics 2005, 7, 335-358. [CrossRef]

118. Huerta de Soto, J.; Sánchez-Bayón, A.; Bagus, P. Principles of monetary \& financial sustainability and wellbeing in a post-COVID19 world: The crisis and its management. Sustainability 2021, 13, 4655. [CrossRef]

119. Bagus, P.; Peña-Ramos, J.A.; Sánchez-Bayón, A. COVID-19 and the political economy of mass hysteria. Int. J. Environ. Res. Public Health 2021, 18, 1376. [CrossRef] [PubMed]

120. Panorama Social de América Latina 2020. Available online: https://www.cepal.org/es/publicaciones/46687-panorama-socialamerica-latina-2020 (accessed on 13 November 2021).

121. Rizzo, M.J.; Whitman, D.G. The knowledge problem of new paternalism. Brigh. Young Univ. Law Rev. 2009, 2009, 905-968. [CrossRef]

122. Rizzo, M.J.; Whitman, D.G. Little brother is watching you: New paternalism on the slippery slopes. Ariz. Law Rev. 2009, 51, 685-739. [CrossRef]

123. O'Driscoll, G.P., Jr.; Rizzo, M. Austrian Economics Re-examined: The Economics of Time and Ignorance; Routledge: New York, NY, USA, 2014

124. Davidson, P. The economics of ignorance or ignorance of economics? Crit. Rev. 1989, 3, 467-487. [CrossRef]

125. Hülsmann, J.G. Economic science and neoclassicism. Q. J. Austrian Econ. 1999, 2, 3-20. [CrossRef]

126. Murphy, R.H. The long-run effect of government ideology on economic freedom. Econ. Aff. 2019, 39, 101-114. [CrossRef]

127. Kimm Gnangnon, S. Economic complexity and poverty in developing countries. Econ. Aff. 2021, 41, 416-429. [CrossRef]

128. Carden, A.; Hall, J. Why are some places rich while others are poor? The institutional necessity of economic freedom. Econ. Aff. 2010, 30, 48-54. [CrossRef]

129. Shand, A. The Failure of 'Market Failure'. Econ. Aff. 1987, 7, 21-25. [CrossRef]

130. Booth, P. Market failure: A failed paradigm. Econ. Aff. 2008, 28, 72-74. [CrossRef]

131. Cachanosky, I. En defensa del monopolio competitivo. Procesos De Merc. 2020, 17, 233-264. [CrossRef]

132. Espinosa, V.I.; Peña-Ramos, J.A.; Recuero-López, F. The political economy of rent-seeking: Evidence from spain's support policies for renewable energy. Energies 2021, 14, 4197. [CrossRef]

133. Boettke, P.J.; Candela, R.A. The liberty of progress: Increasing returns, institutions, and entrepreneurship. Soc. Philos. Policy 2017, 34, 136-163. [CrossRef]

134. Acemoglu, D.; Robinson, J.A. Rents and economic development: The perspective of Why Nations Fail. Public Choice 2019, 181, 13-28. [CrossRef]

135. Acemoglu, D.; Naidu, S.; Restrepo, P.; Robinson, J.A. Democracy does cause growth. J. Political Econ. 2019, 127, 47-100. [CrossRef]

136. Kamerlin, S.C.; Kasson, P.M. Managing Coronavirus Disease 2019 spread with voluntary public health measures: Sweden as a case study for pandemic control. Clin. Infect. Dis. 2020, 71, 3174-3181. [CrossRef]

137. Kähler, M.T. How Behavioral Economics can enrich the Perspective of the Austrian School. Procesos De Merc. 2018, 15, 257-268. [CrossRef]

138. Hayek, F.A. The fatal conceit: The errors of socialism. In The Collected Works of Friedrich August Hayek; Bartley, W.W., III, Ed.; Routledge: New York, NY, USA, 1988; Volume I. 